\title{
一般 18
}

\section{血清尿酸高值と心房細動の関連への利尿薬投与の影響について}

\section{背景および目的}

血清尿酸值が高值である症例において心房細動 (AF)の頻度が高いことが, いくつかの横断的研究, 縦断的研究で示されてきた。一方, $\mathrm{AF}$ 症例は, さまざまな心疾患を有する高齢者に比較的多く, 心不全に対して利尿薬が投与されているケースも 少なくないと考えられる，そのため，利尿薬によ る尿酸の上昇が見かけ上の関連に寄与している可 能性もあると推定される。 今回われわれは，循環 器内科入院患者を対象に, 利尿薬投与の有無を考 慮したモデルで，血清尿酸值 (SUA) 高值と心房細 動の関連に検討した。

\section{方 法}

2012 年 1 月 - 2014 年 3 月の間に当院循環器内科 に入院し, 本研究に対して同意が得られた症例の うち, 20 歳以下, カテーテルアブレーションの 既往, 維持透析, 尿酸降下薬内服中の患者を除外 した 918 症例 (女性：270症例, 男性：648症例) を対象として，AFと尿酸の関連を検討した。

\section{結 果}

心房細動群(AF群) は 122 例 (13\%), 非心房細動 群 (非 $\mathrm{AF}$ 群)は796例 (87\%) であった。 $\mathrm{AF}$ 群は平 均年齢 72.1 歳と非 $\mathrm{AF}$ 群の 69.0 歳より有意に高齢 であった $(\mathrm{p}=0.003) . \mathrm{AF}$ 群で $\mathrm{SUA}$ は $6.4 \mathrm{mg} / \mathrm{dL}$ と
坂根 和志 藤田 修一 岡本 祐典 木澤隼宮村 昌利 石坂 信和

非 $\mathrm{AF}$ 群の $5.7 \mathrm{mg} / \mathrm{dL} よ り$ 有意に高值であった $(\mathrm{p}<0.001) . \mathrm{AF}$ 群では, 予想どおり, 非 AF群と比 較して，ループ利尿薬 (16.5\% vs 48.4\%, p <0.001), サイアザイド系利尿薬 $(4.5 \%$ vs 9.0\%, p=0.046)の いずれの投与も多かった。

次に, $\mathrm{AF}$ 従属変数として, ロジスティク回 帰分析を行った。 SUAの高值 (5.9 mg/dL 以上)は, 単変量解析で $\mathrm{AF}$ とオッズ比 $2.58(\mathrm{p}<0.001)$ で有意 な関連を有していた。また，年齢，性別，腎機能 (eGFR), BNPに加え, 利薬投与を共変量として 投入したモデルにおける検討でも，SUA高值は オッズ比 $1.74(\mathrm{p}=0.027)$ と $\mathrm{AF}$ と独立した関連を有 していた。 なお，このモデルでは，ループ利尿薬 およびサイアザイド系利尿薬の投与は，それぞれ オッズ比 $1.93(\mathrm{p}<0.01), \quad 2.98(\mathrm{p}<0.01)$ で AF と関連 していた．対象症例を利尿薬投与の有無でサブグ ループに分けた検討では, SUAとAFの関連は利 尿薬投与群でのみ有意であった。

\section{結 語}

循環器症例において年齢, 腎機能, 利尿薬の投 与の有無などとは独立して SUAは AF と関連して いた，SUA高值に対する治療介入がAFの発症や 再発の抑制につながるかどうかについては今後の 課題であると考える.

大阪医科大学 循環器内科 Kazushi Sakane, Shuichi Fujita, Yusuke Okamoto,

Shun Kizawa, Masatoshi Miyamura, Nobukazu Ishizaka 